\title{
Small-scale physical modelling of scour at bridge piers with light-weight sediments
}

\author{
S. Perrin \\ ARTELIA Eau \& Environnement, Grenoble, France \\ C. Keppers, S. Roux \\ ARTELIA International, Dubai, United Arab Emirates \\ E. Murphy \\ Golder Associates, Vancouver, Canada
}

\begin{abstract}
This study entailed physical model testing to support the design of marine facilities associated with a proposed $36 \mathrm{~km}$ long causeway, which is under construction in Kuwait Bay. The marine facilities include 1050 bridge piers, to be built in varying conditions in terms of water depth, soil conditions, current and wave conditions. Seabed levels vary from intertidal to approximately $-12 \mathrm{~m}$ MSL and three different types of seabed material were observed: cap-rock underlain by sand, silty sand and silty clay. Light-weight sediment physical models with scales 1:20 and 1:37 were used to assess scour potential due to waves and currents at the base of the bridge piers and to guide the design of scour protection (rock armouring of the seabed). The PVC light-weight particles used to model the prototype silty sand had a density of approximately $1200 \mathrm{~kg} / \mathrm{m}^{3}$ and a median diameter $\left(\mathrm{d}_{50}\right)$ of $0.25 \mathrm{~mm}$. Quantitative assessments of the seabed evolution were made with advanced photo-scan techniques. The model results provide insight to the evolution of scour over time and equilibrium scour hole dimensions, which were compared to predictions using empirical formulae. The similitude laws that apply for this type of model and observed model effects are also discussed.
\end{abstract}

\section{INTRODUCTION}

This study entailed physical model testing to support the design of marine facilities associated with a proposed $36 \mathrm{~km}$ long causeway, which will connect the northern region of Kuwait (Subiyah) to the southern region (Kuwait City). The causeway is a combination of low-level bridges, embankments and two transition islands. Construction is underway and completion is scheduled in 2018. In total, 1050 bridge piers will be constructed in Kuwait Bay. Water depths, soil conditions, currents and wave conditions vary along the causeway alignment. Various numerical models have been applied to determine the critical combinations of wave heights and tidal currents to which the scour protection will be exposed. Light-weight sediment physical models with scales 1:20 and 1:37 were used to assess scour potential due to waves and currents at the base of the bridge piers and to guide the design of scour protection (rock armouring of the seabed). The size and density of the light-weight sediments were determined by taking into consideration the similarity of the physical model to the prototype in terms of the hydrodynamic regime, conditions for initiation of sediment motion, modes of sediment transport, sediment size to pier size ratio, and sediment grading. The scour hole development around the piers was measured in the laboratory for the design conditions and compared with scour hole estimates from empirically-based prediction methods. The evolution of the seabed morphology was monitored visually during the testing. Quantitative assessments of the seabed evolution were also made with advanced photoscan techniques. The model development and testing was undertaken at ARTELIA's hydraulics laboratory in Grenoble, France.

\section{SITE CONDITIONS}

The bathymetry in Kuwait bay is shown in Figure 1 along with the locations considered for physical model testing. Seabed levels along the causeway alignment vary from intertidal to approximately -12 $\mathrm{m}$ MSL (Mean Sea Level). Geotechnical investigations along the causeway corridor identified three distinct seabed material types in different areas: caprock underlain by sand between Shuwaikh and Bay Island South, silty sand just North of Bay Island South and silty clay over the largest part of the causeway. The threshold bed shear-stress for mobilization of these types of sediments was estimated based on literature and ranges from approximately 0.1 to $0.2 \mathrm{~N} / \mathrm{m}^{2}$ for the silty sand to sand material (Soulsby, 1997), to between 3 and $12 \mathrm{~N} / \mathrm{m}^{2}$ for the more cohesive, silty clay (Nielsen et al. 2001). 


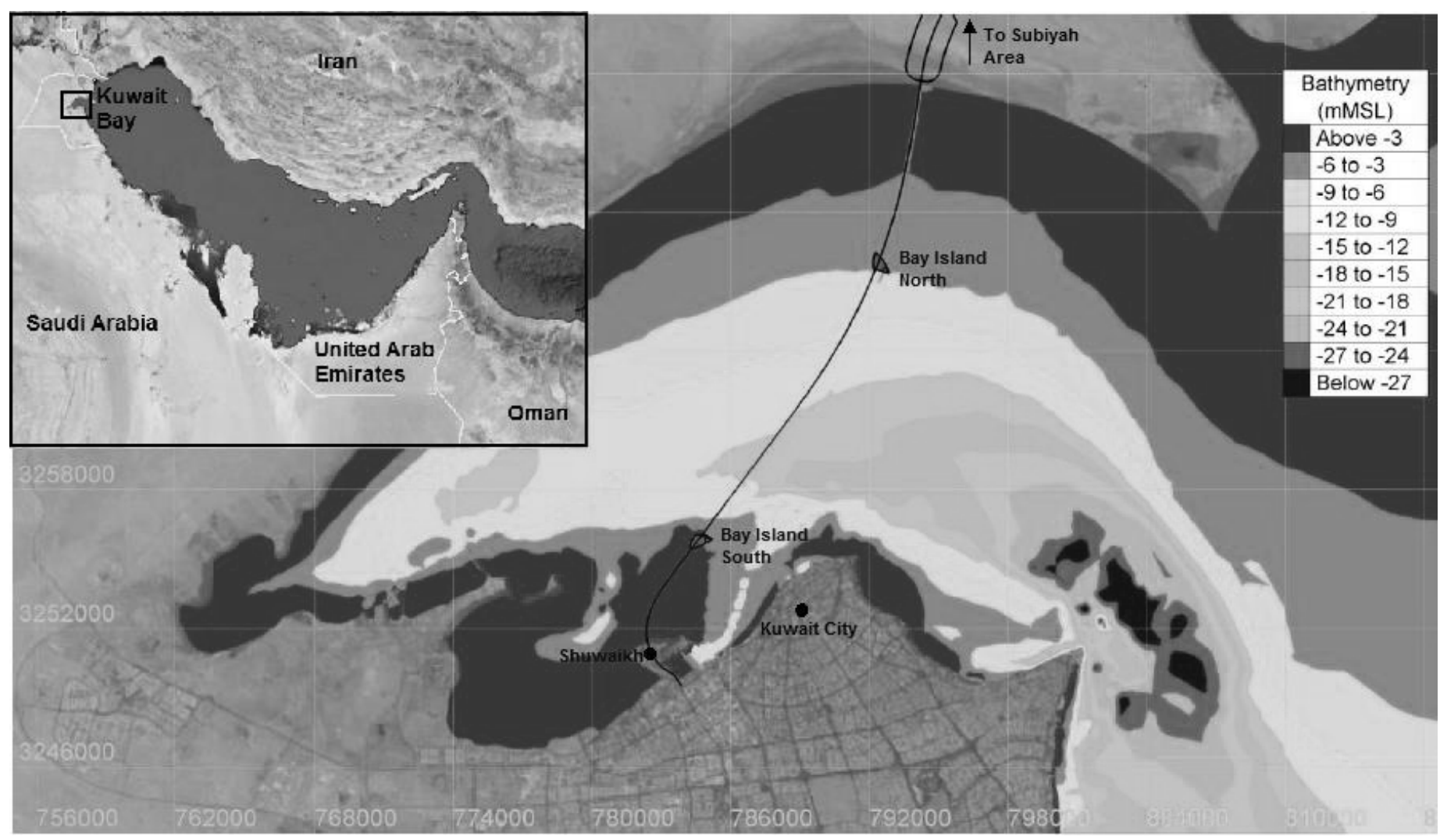

Figure 1. Bathymetry

A wave transformation study was implemented using a SWAN numerical model (Delft University of Technology, 2011) to determine the extreme (storm) wave conditions at the project site. Design spectral significant wave heights of $1.9 \mathrm{~m}$ and $2.2 \mathrm{~m}$ were estimated for the 100 year and 2000 year return periods, respectively. These sea states were associated with positive storm surges of $1.34 \mathrm{~m}$ (100 year return period) and $1.74 \mathrm{~m}$ (2000 year return period). A TELEMAC-2D flow model (Hervouet, 2007) was developed to simulate tidal currents at the project site. The hydrodynamic model was calibrated against current profile measurements at two locations in the vicinity of Bay Island North and Bay Island South. Maximum depth-averaged tidal current speeds were predicted to reach $0.8 \mathrm{~m} / \mathrm{s}$ at the site.

\section{BRIDGE PIER AND SOUR PROTECTION DESIGN}

Bridge piers modify wave- and current- induced hydrodynamics, resulting in local amplification of bed shear-stresses: by up to a factor of 11 according to experiments by Hjorth (1975). Local exceedance of the threshold bed shear-stress for incipient sediment motion is a condition for the initiation of erosion (scour) around the base of a pier, which can ultimately develop and undermine the bridge integrity. Actual bed shear-stresses at the site can reach up to 1 $\mathrm{N} / \mathrm{m}^{2}$ due to combined waves and currents, exclud- ing local influences due to the presence of piers. As peak bed shear-stresses exceed the threshold criteria for incipient motion of in situ sediment, seabed materials are expected to be mobilized by waves and currents outside the area influenced by the proposed bridge piers, referred to as a "live bed" regime. For periods of very weak currents (e.g. slack tide), design wave conditions result in Keulegan-Carpenter (KC) numbers in the range 0.2 to 1.5 , therefore less than values required for the onset of scour due to waves (Sumer et al., 1997).

Scour protection measures, consisting of a rock apron, were proposed at the base of the cylindrical bridge piers to mitigate the risks of scour due to combined waves and currents. The rock stability was assessed based on the Shields criterion, which represents the critical value of the ratio of the destabilizing fluid forces to stabilizing forces acting on the rocks (including self-weight). A critical Shields parameter of 0.03 was used to determine the threshold for incipient motion of the rock. The rock scour protection was designed to remain stable under combined wave and current conditions, including a combination of peak spring tidal current speeds and 100 year return period waves. The maximum shear stresses due to this combination of waves and tidal currents was calculated at $50 \mathrm{~m}$ intervals along the entire causeway, based on the results of the hydrodynamic and wave propagation modelling. Local increases in bed shear-stress due to the presence of the bridge piers was estimated using an amplification 
factor of 2 for waves and 10 for currents, based on values presented by Whitehouse (1998). The minimum rock mass required to meet the Shields criterion was assessed. A median rock mass of $50 \mathrm{~kg}$ was adopted for design purposes.

The configuration of the bridge piers and scour protection is shown in Figure 2. The proposed bridge deck is supported by groups of two $3 \mathrm{~m}$-diameter piers at center-to-center distances of $19 \mathrm{~m}$. The proposed rock apron (scour protection) is conical with a maximum radius of $6 \mathrm{~m}$ at the seabed, and a vertical thickness of $1.3 \mathrm{~m}$ (including a gravel filter). The proposed scour protection consists of 20 to $100 \mathrm{~kg}$ graded rock with the median mass exceeding $50 \mathrm{~kg}$. The rock and filter material will be placed in an excavation around the base of each bridge pier with side slopes 1:4 (vertical to horizontal).
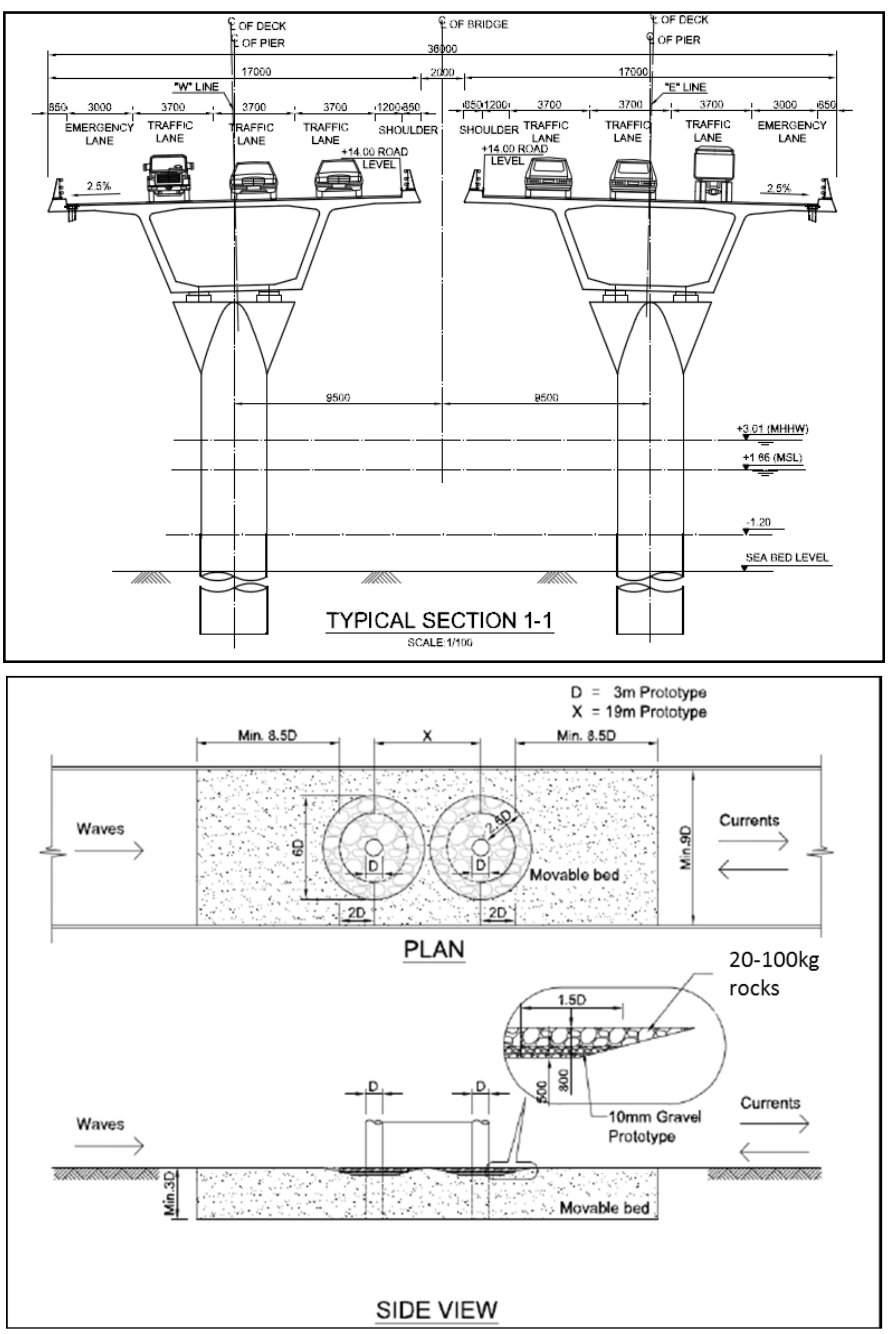

Figure 2. Bridge pier and scour protection configuration

\section{METHODOLOGY}

\subsection{Objectives}

The objectives of the physical model study were: (i) to examine the development and evolution of the scour geometry around unprotected piers; and (ii) to assess the stability of the rock in the scour protec- tion. The study also provided insight to bedform (ripple) development and ripple heights.

\subsection{Scaling}

Correctly modelling hydrodynamic conditions is a prerequisite for studying scour, which is driven by the formation of horseshoe vortices around the bridge piers. At model scale, water depth Reynolds numbers were in the range 15000 to 160000 , meaning the influence of fluid viscosity was considered negligible compared to gravity and inertia on the scale of the water depth (Hughes, 1993). Froude scaling was consequently used to scale wave and current parameters, and the geometric dimensions of the piers and scour protection. Considering practicalities related to the test facilities and the model setup, model scales of 1:20 and 1:37 were selected for both shallow and deep locations respectively (Figure 2).

The size and density of the model sediments were selected with the following considerations:

- The hydrodynamic regime (laminar, turbulent or intermediate) at the scale of sediment grains must be similar in the model to the prototype. The grain Reynolds number $\left(\mathrm{Re}^{*}\right)$ values must be of the same order of magnitude [typically $\mathrm{Re}^{*}{ }_{\mathrm{m}}=\mathrm{O}$ $\left.\left(\operatorname{Re}_{\mathrm{p}}{ }_{\mathrm{p}}\right)\right]$. In our case, $\mathrm{Re}^{*}$ values in the range of 1.8 to 3.5 were estimated outside of the influence of the piers, which indicated a flow regime dominated by viscosity (laminar regime).

- It was important that the conditions of initiation of sediment motion for the physical model were similar to prototype conditions as the scour depth is a function of the Shields parameter $(\Theta)$ close to the threshold Shields parameter $\left(\Theta_{c}\right)$ (Melville and Coleman, 2000). This requirement is expressed as $\left(\Theta_{\mathrm{m}}-\Theta_{\mathrm{mcr}}\right) / \Theta_{\mathrm{mcr}} \sim\left(\Theta_{\mathrm{p}}-\Theta_{\mathrm{pcr}}\right) / \Theta_{\mathrm{pcr}}$ for $\Theta_{p} \sim \Theta_{p c r}$, where subscripts $m$ and $p$ refer to model and prototype conditions, respectively.

- The mode of sediment transport (e.g. bed load or suspended load) must be similar to prototype conditions. This condition implies that the Rouse number (s) must be in the same range in the model and prototype $\left(\mathrm{s}_{\mathrm{m}} \sim \mathrm{s}_{\mathrm{p}}\right)$. Calculated Rouse numbers for prototype conditions were in the range of 0.4 to 0.7 , which indicated suspension as the dominant mode of sediment transport.

- The water depth to pier size ratio (1.1 to 4.8) must be correctly represented as this parameter significantly influences the scour depth for ratios smaller than 4 (Melville et al., 1988).

- The sediment grain size $\left(d_{50}\right)$ to pier diameter (D) ratio must be respected as this parameter influences scour if $\mathrm{D} / \mathrm{d}_{50}<50$ (Breusers and Raudkivi, 1991).

- Sediment grain size distributions (gradation) in the 
model must be similar to prototype conditions, in order to avoid unrepresentative armouring effects at model scale (Sumer and Fredsoe, 2002). A grading index $\left(\mathrm{D}_{84} / \mathrm{D}_{16}\right)$ of approximately 2 was adopted, which is typical of well sorted marine sand.

- The slope angle in an unprotected scour hole at equilibrium is expected to be, for a non-cohesive material, similar to the natural angle of repose. The slope angle increases with decreasing material density and with increasing sediment diameters (Migniot, 1977).

Of the three characteristic seabed materials identified at the site, the silty sand is associated with the lowest threshold bed shear-stress for initiation of motion, and was therefore selected for model testing. Plastic light-weight sediments with a density of approximately $1200 \mathrm{~kg} / \mathrm{m}^{3}$ and a median diameter $\left(\mathrm{d}_{50}\right)$ of $0.25 \mathrm{~mm}$ were used in the models. Preliminary tests whereby current speeds were incrementally increased in the model demonstrated that the threshold depth average current speed (U) for incipient motion of the light-weight sediments was in the range 0.05 to $0.10 \mathrm{~m} / \mathrm{s}$, which corresponds to threshold bed shear-stresses in the range 0.01 to $0.03 \mathrm{~N} / \mathrm{m}^{2}$.

\subsection{Setup}

The model was constructed in a circulating flume, approximately $3 \mathrm{~m}$ wide and $40 \mathrm{~m}$ long. The test zone was $3 \mathrm{~m}$ wide by $4 \mathrm{~m}$ long and $0.3 \mathrm{~m}$ deep. The model pier diameter to flume width ratio $(\mathrm{D} / \mathrm{W})$ was between $1 / 20$ and $1 / 40$, below the limit of $1 / 6$ to avoid flow constriction effects (Whitehouse, 1998).

The depth of the test zone (the pit where the lightweight sediments were placed) was equivalent to 2 and 3.7 times the pier diameters depending on the scale considered. The reported extent of scour depth for circular piers is 1 to 2.5 times the diameter ( $\mathrm{Su}-$ mer \& Fredsoe, 2002).

The prototype pier configuration as shown in Figure 2 was correctly represented at model scale. It was important that the model pier spacing to pier diameter ratio (X/D) was kept the same as the prototype to ensure the effects of adjacent piers on scour was correctly represented, which become important for $\mathrm{X} / \mathrm{D}<15$. For the project pier configuration (X/D approximately equal to 6 ), an increase of 0 to $15 \%$ of the scour depth compared to a single pier was expected at the front pier (Breusers \& Raudviki, 1991). The pier shape was also identical at model scale compared to prototype scale as this has a significant effect on scour depth (Sumer and al., 1993). The two piers were also aligned with the current and wave directions in accordance with conditions on site, as the alignment of piers to the flow is known to disturb the flow pattern around bridge piers if the spacing between the piers is less than 3 to 11 times the pier diameters (Hoffmans \& Verheij, 1997). Piers were manufactured with mortar and graduated to facilitate visual assessment of the scour depth during the course of each test.

The circulating flume was equipped with a piston-type wave generator, and a current generator capable of producing currents in the same or opposite direction to the waves. A sediment feed system was also installed on both sides of the test section to maintain an equilibrium bed outside the influence of the piers. The volumes of sediments to be fed in the flume were estimated prior to testing, using the Soulsby - Van Rijn formulae as described in Soulsby (1997). Sediments were fed into the flume at a rate varying between 1.1 and $5.5 \mathrm{~m}^{3} /$ hour $/ \mathrm{m}$.

\subsection{Wave and current calibration}

Calibration of the model current speeds was carried out based on measurements at elevations corresponding to one third of the water depth above the model seabed. Target current speeds at this elevation approximately correspond to depth averaged current speeds (Soulsby, 1997). For each test condition, the current generator was adjusted to obtain a reasonable match with the target values. Measured current speeds were typically within $\pm 0.1 \mathrm{~m} / \mathrm{s}$ (prototype) of target current speeds and in all cases were within $\pm 0.2 \mathrm{~m} / \mathrm{s}$ of target values. Calibration of wave parameters involved verifying that model spectral significant wave heights $\left(\mathrm{H}_{\mathrm{m} 0}\right)$ and spectral peak periods $\left(T_{P}\right)$ were within $\pm 5 \%$ of target values. Timeaverage velocity profiles measured during testing for the deep water location are shown in Figure 3.

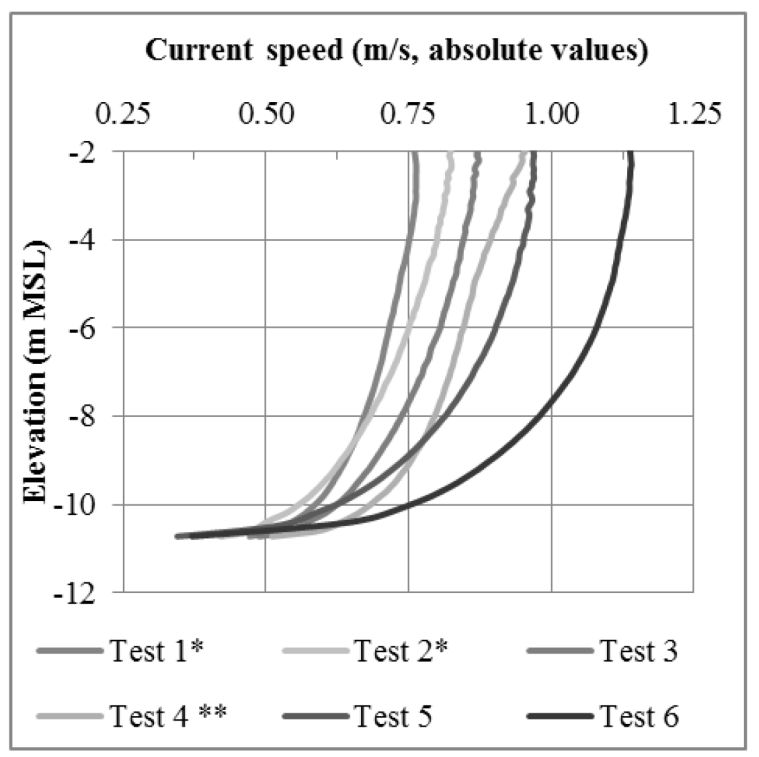

Figure 3. Measured velocity profiles for the deep water location tests - prototype values (* indicates current only, ** indicates current direction opposing waves, otherwise waves and currents are in the same direction) 


\subsection{Monitoring of seabed evolution}

The evolution of the seabed morphology was visually monitored during model testing. Graduations on the side of the piers were used to estimate the time of establishment of the equilibrium scour depth. A series of photographs showing the evolution of the seabed at the deep water location for a test with currents only $(\mathrm{U}=1.2 \mathrm{~m} / \mathrm{s})$ is shown in Figure 4 . The scour depth at time $\mathrm{T}=1,6$ and 12 hours (Froude prototype scale) was measured during the course of testing using the markers placed on the pier surface. Scour depths measured immediately adjacent to the piers did not correspond to the maximum scour depths, which typically occurred at some distance from the piers.

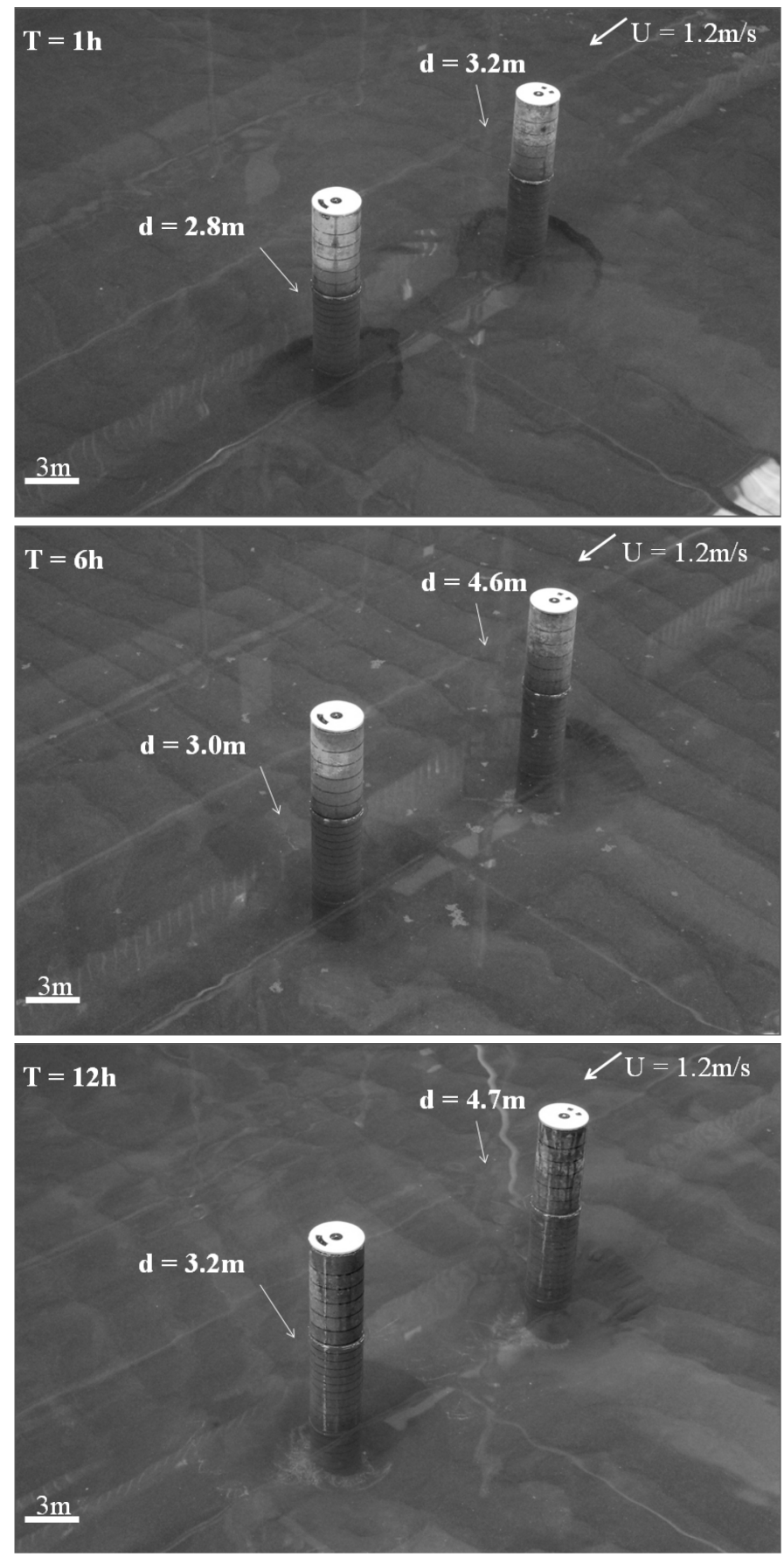

Figure 4. Photographs showing seabed morphology at times ( $1 \mathrm{~h}, 6 \mathrm{~h}$ and $12 \mathrm{~h}$ ) following the start of a model test
Quantitative evaluations of seabed morphology change were conducted by comparing photo-scan surveyed seabed levels at the end of each test to the initial seabed levels. The photo-scan surveying technique involved photographing the test zone from different viewpoints using a mono-focal camera (60 photographs), followed by spatially referencing ( $\mathrm{x}, \mathrm{y}$, and $\mathrm{z}$ co-ordinates) the pixels composing each photograph using coefficients that were previously calibrated with 6 known benchmarks. Finally, a digital elevation model was constructed by interpolating the positions from all 60 photographs. The accuracy in terms of the surveyed seabed elevations was generally within 0.1 to $0.2 \mathrm{~m}$, except in close proximity to the piers where the precision was less than $0.4 \mathrm{~m}$. Bathymetry contours surveyed using the photo-scan technique at the end of a test for the deep water location ( $\mathrm{U}=0.8 \mathrm{~m} / \mathrm{s}$ and no waves) is shown in Figure 5 .

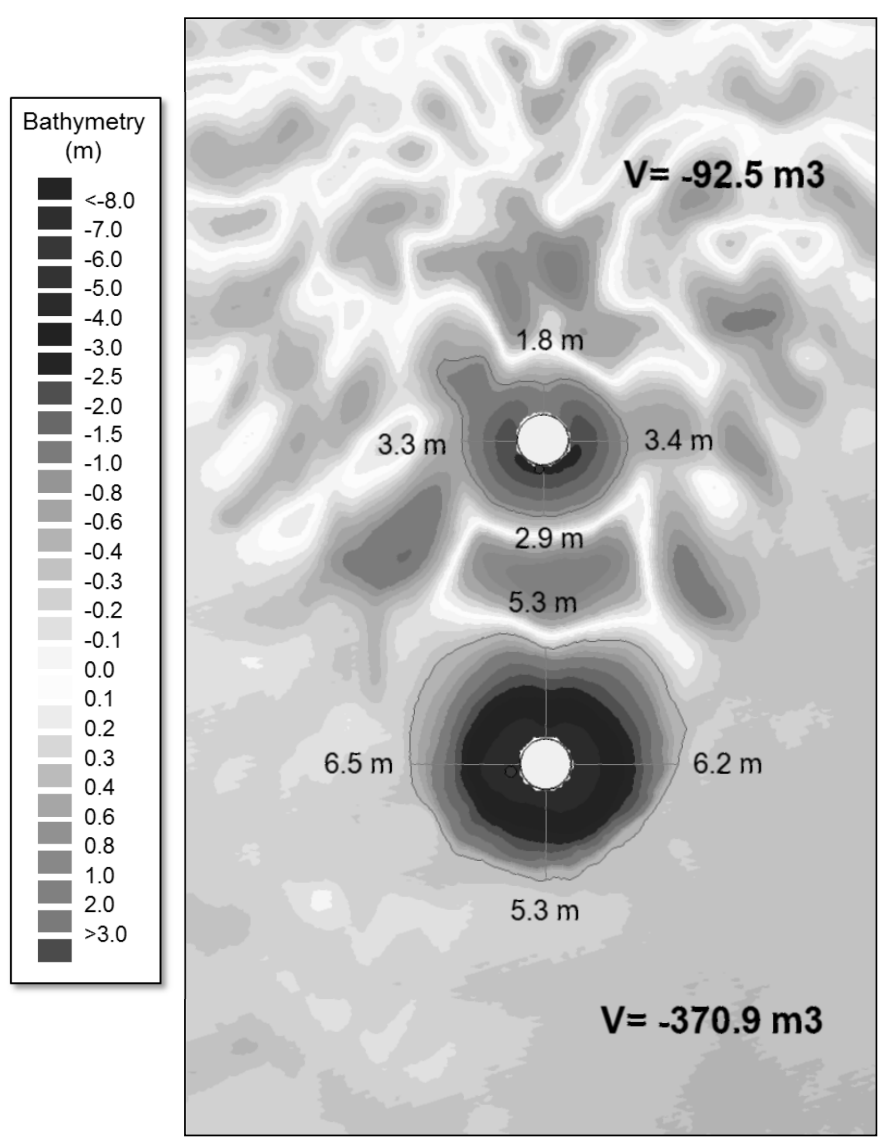

Figure 5. Photo-scan surveyed bathymetry (prototype elevations) at $\mathrm{T}_{\text {model }}=2$ hours

\subsection{Monitoring of damage to scour protection}

Stability of the rock comprising the scour protection was visually assessed during testing and documented using photographs taken before and after each test. Damage was quantified based on the number of rock extractions and number of rock layers remaining in place at the end of each test. To facilitate the damage assessment, coloured paint was applied to rocks prior to testing, providing visual references to identify 
different areas where rocks were displaced during tests.

The scour protection at the shallow water location following 12 hours of testing at Froude prototype scale $\left(\mathrm{H}_{\mathrm{m} 0}=1.4 \mathrm{~m}, \mathrm{~T}_{\mathrm{P}}=5.4 \mathrm{~s}\right.$, and $\mathrm{U}=0.43 \mathrm{~m} / \mathrm{s}$ opposing waves) is shown in Figure 6.

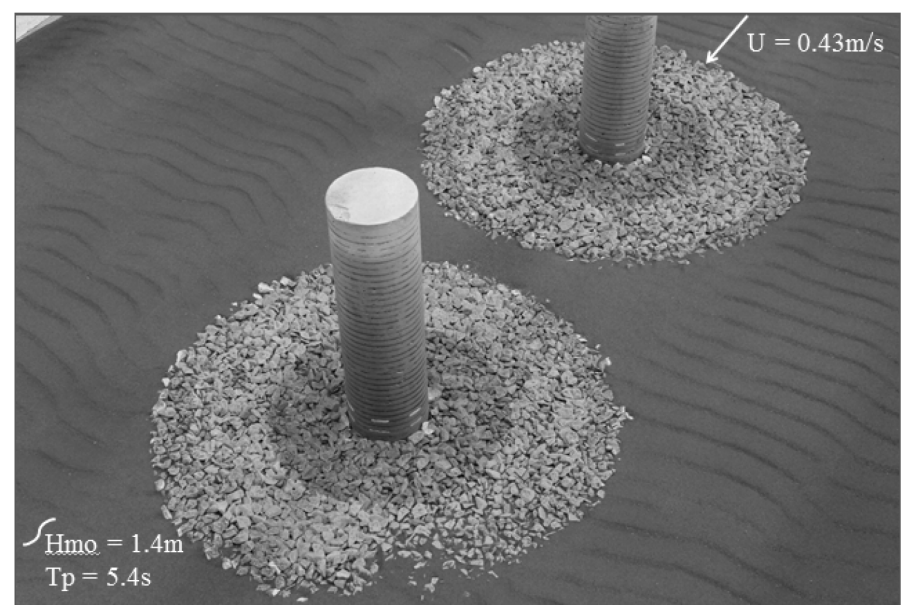

Figure 6. Photograph of the scour protection model at the shallow water location following 12 hours of testing (Froude protype scale)

\subsection{Model effects}

During the tests, two model effects were observed. Lowering of seabed elevations occurred along the upstream model boundary, which was attributed in part to a shortage in the supply of sediments upstream for bed-load transport. This erosion was also likely created due to the abrupt change in roughness between the fixed concrete seabed upstream of the test zone and the mobile seabed made of lightweight sediments. As a mitigating measure, a nonerodible gravel transition was placed at the interface between the concrete and the mobile sea bed. Additional light-weight sediment was also deposited on the concrete seabed upstream of the test zone. Water was systematically sprayed into the flume to counteract surface tension effects, to prevent light-weight sediments floating to the surface.

\section{RESULTS}

During each test the following observations or measurements were made:

- Scour dimensions at the two piers: maximum scour depth (S), maximum in-line width $\left(\mathrm{W}_{1}\right)$, maximum cross-wide width $\left(\mathrm{W}_{2}\right)$;

- Duration to reach the scour equilibrium $\left(\mathrm{T}^{*}\right)$;

- Volume of sediment eroded from the scour hole (V);

- Ripple dimensions: ripple height (h) and ripple length (1);

- Number of extracted rocks $(\mathrm{N})$ and their locations before extraction with respect to the piers.
The following figure shows the time-varying average value of the visually recorded scour depth (S) compared to the scour depth $\left(\mathrm{S}_{\mathrm{f}}\right)$ recorded at the end of testing.

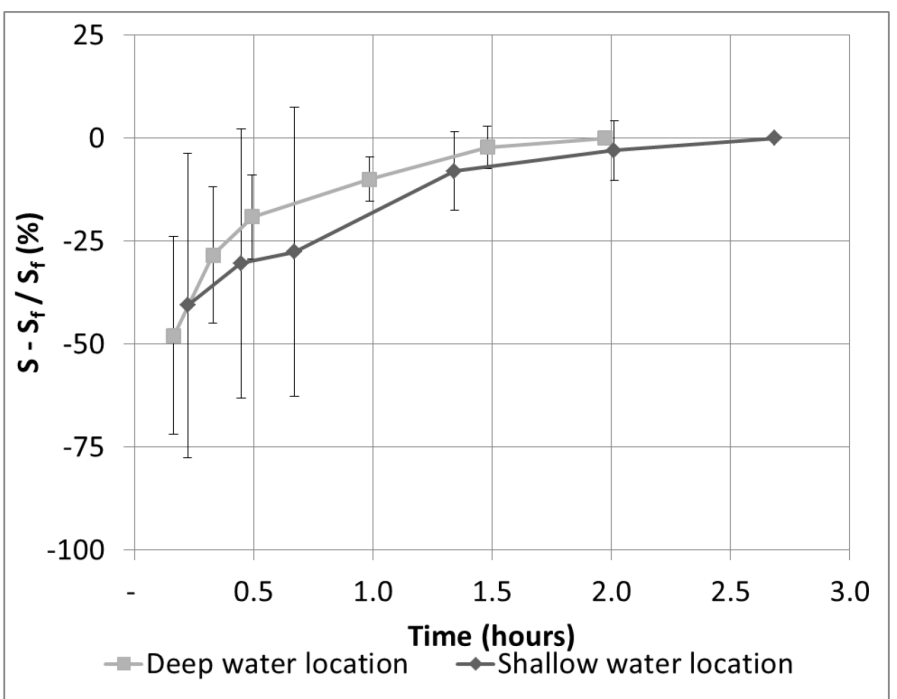

Figure 7. Time evolution of $\mathrm{S}-\mathrm{S}_{\mathrm{f}} / \mathrm{S}_{\mathrm{f}}$ the scour depth ratio (mean, standard deviation) at the deep location (10 tests) and at the shallow water location (10 tests) for both piers

The rate of scour was seen to decrease progressively during the course of testing. A significant amount of scour took place rapidly: the scour depth generally reached $50 \%$ and $75 \%$ of its final recorded value at $\mathrm{T}=0.5 \mathrm{~h}$ and $\mathrm{T}=1 \mathrm{~h}$, respectively. Despite the strong variability observed at the beginning of testing due to the difference in severity of the hydrodynamic conditions, the rate of scour reached a plateau toward the end of testing which indicated that equilibrium conditions were approached: for the deep water location, the scour depth recorded at $\mathrm{T}=1.5 \mathrm{~h}$ was generally within less than $2 \%$ of the final recorded value (at $\mathrm{T}=2 \mathrm{~h}$ ); for the shallow water location, the scour depth recorded at $\mathrm{T}=2 \mathrm{~h}$ was generally within less than $3 \%$ than the final recorded value (at $\mathrm{T}=2.7 \mathrm{~h}$ ).

At the end of the tests, surveyed maximum scour depths (measured from the initial seabed) were in the range of 0.6 to $3.7 \mathrm{~m}$ (prototype) at the shallow water location, equivalent to scour depth to pier diameter ratios $(\mathrm{S} / \mathrm{D})$ of 0.2 to 1.2 . Scour depths were in the range 3.1 to $5.6 \mathrm{~m}$ at the deep water location, corresponding to $\mathrm{S} / \mathrm{D}$ values in the range of 1.7 to 2.1. For the shallow water location, the empirical predicted scour depth to pier size ratio was calculated in the range of 1.7 to $1.9,1.2$ to 1.4 , and 0.7 to 0.8 when using the empirical formulae developed by Melville and Sutherland (1988), Breusers et al. (1997), and Csu model (envelop curve as described in Hoffmans \& Verheij (1997)) respectively. For the deeper location predicted values using the same formulations were $2.4,1.5$, and 1.1 to 1.3 . Although these formulae are strictly valid for piers in steady currents only, $\mathrm{KC}$ numbers were less than 1.5 for all tests, indicating a current-dominated scour regime. 
S/D predictions using (Zanke et al., 2011) formula, applicable for combined currents and short waves, are in the range of 0.4 to 0.9 and 1.1 to 2.2 for the shallow and deep locations respectively.

Surveyed maximum scour widths were in the range of 0.0 to $8.1 \mathrm{~m}$ in an alignment parallel to the directions of waves and currents, which corresponded to a scour width to pier diameter ratio $\left(\mathrm{W}_{1} / \mathrm{D}\right)$ of 0.0 to 2.7. The maximum width of the scour hole perpendicular to the direction of waves and currents were in the range 0.0 to $6.6 \mathrm{~m}$, corresponding to $\mathrm{W}_{2} / \mathrm{D}$ of 0.0 to 2.2 . The volume of eroded material varied between 0.5 and $427 \mathrm{~m}^{3}$, which correspond to $\mathrm{V} / \mathrm{D}^{3}$ ratios in the range of 0.1 to 15.8 . $\mathrm{S} / \mathrm{D}$. $\mathrm{V} / \mathrm{D}^{3}$ values are plotted against $\Theta-\Theta_{\mathrm{cr}} / \Theta_{\mathrm{cr}}$ in Figure 8. The evolution of the scour depth to pier diameter ratio with time is shown in Figure 7 for the deep water location at the upstream pier.

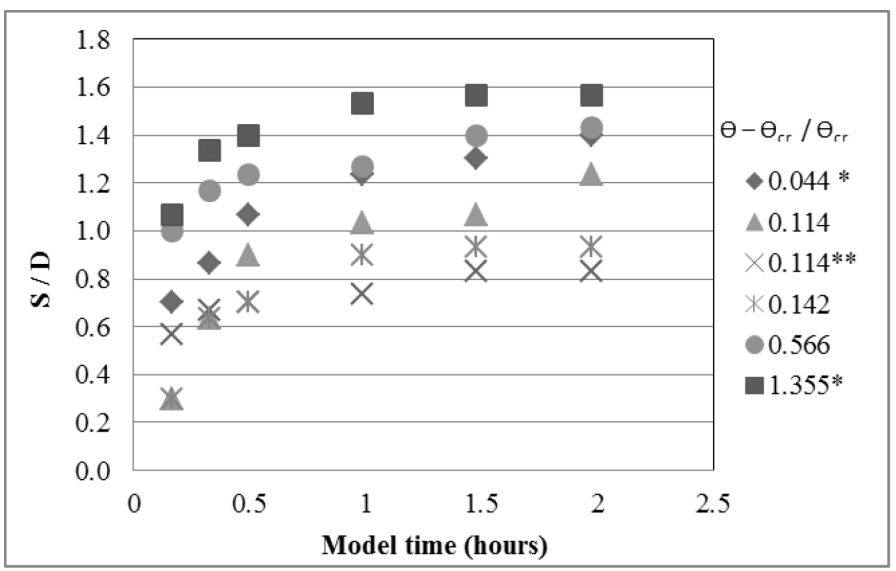

Figure 8 . Time evolution of $\mathrm{S} / \mathrm{D}$ ratio at the upstream pier for the deep water location $(*$ indicates currents only, ** current direction opposing waves, otherwise waves and currents in the same direction)

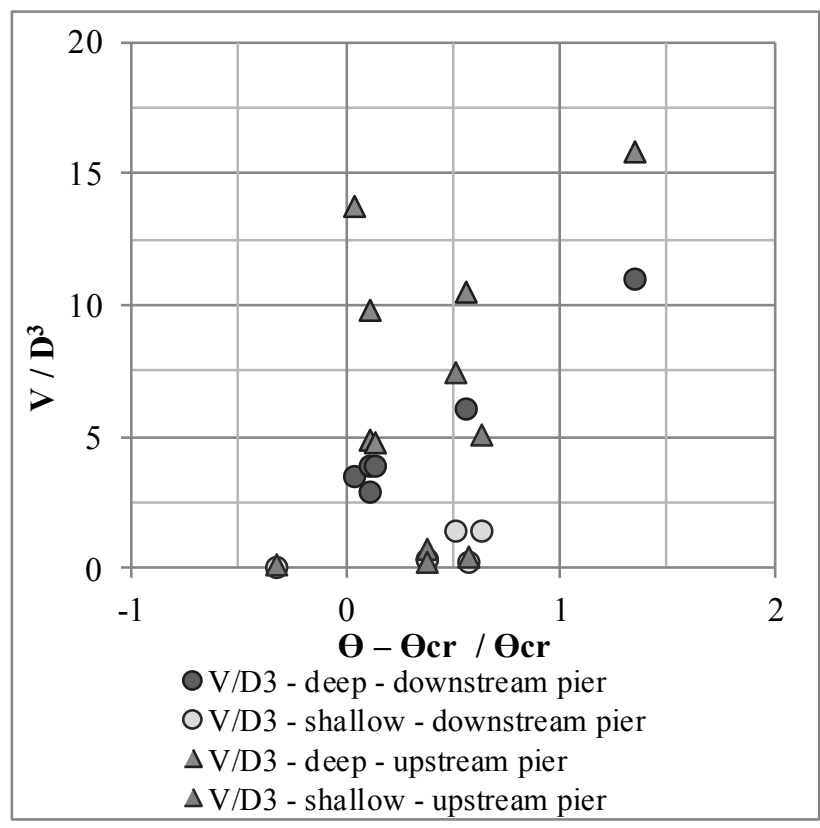

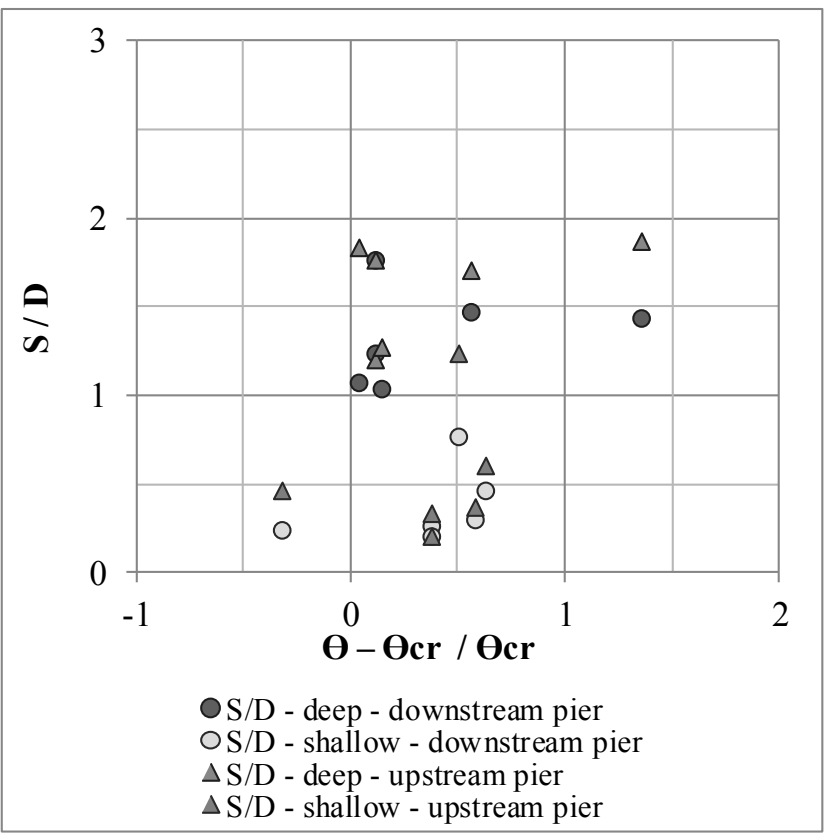

Figure 9. $\mathrm{S} / \mathrm{D}$ ratio (bottom) and $\mathrm{V} / \mathrm{D}^{3}$ ratios (top) for all tests

Scour depth and volume to pier size ratios $(\mathrm{S} / \mathrm{D}$, $\mathrm{V} / \mathrm{D}^{3}$ ) generally increase with increasing Shields ratios $\left(\Theta-\Theta_{\text {cr }} / \Theta_{\text {cr }}\right)$ (Figures 7 and 8). It can also be observed that the values for the shallow location are consistently lower which is attributed to weaker currents and the larger contribution of waves. Scour was generally more severe at the upstream pier, in the range of 15 to $40 \%$ more than at the downstream pier for wave and current conditions in the same direction, and 30 to $100 \%$ more for currents only. An exception was for tests with opposing waves and currents, where equilibrium scour depths at the upstream pier were equivalent to, or as much as $30 \%$ smaller than at the downstream pier.

The majority of mobilized sediment was transported in suspension at the shallow water location under combined waves and currents. In all other test cases, the mode of transport consisted predominantly of bed-load. Ripples or dunes were visible for tests involving weak currents $(\mathrm{U}=0.43 \mathrm{~m} / \mathrm{s})$ without waves, and currents opposing waves at the shallow water location. Observed ripple heights were in the range 0.1 to $0.8 \mathrm{~m}$ depending on test conditions. This correlated well with the predicted ripple heights in the range 0.1 to $0.9 \mathrm{~m}$ based on Van Rijn 1984), applicable for currents only. Predicted ripple lengths using the same formulae were in the range of 20 to $100 \mathrm{~m}$, which was about 12 to 17 times the measured ripple lengths, following application of the Froude scale ratios. This indicates the non-applicability of Froude scaling for this parameter.

Recommendations were to use the measured scour depth plus 0.5 times the ripple height in the bridge design to account for the fact that ripples have positions which vary in time (Breusers et al., 1977). Rock stability criteria for the scour protection were satisfied, with no more than a few extractions during all tests. 


\section{CONCLUSION}

A mobile-bed physical model incorporating lightweight sediments was developed and used to assess scour at twin cylindrical bridge piers, to support the design of marine facilities associated with a proposed $36 \mathrm{~km}$ long causeway under construction in Kuwait Bay. Scour hole dimensions (depth, width and volumes) and ripple heights were measured in the laboratory using photogrammetric survey techniques and compared to predictions based on empirical formulae, to identify and verify the dominant factors and parameters affecting scour at the bridge piers. The model was used to verify the stability of rock in a proposed seabed protection at the base of the piers, designed to mitigate the risk of destabilizing scour.

\section{ACKNOWLEDGEMENT}

Thanks to Eric De Croutte and Dr. James Walker from Artelia for their input at the start of the study and to Sukrok Jung, Moonkyu Choi and Dr. In-Ho Jang from Hyundai Engineering $\&$ Construction Co. for their input and review during the physical model tests. We would like to thank Dr. Hazem Sarhan, the project management team of Systra and the Ministry of Public Works of Kuwait for their support.

\section{REFERENCES}

Breusers and Raudkivi, 1991, Scouring, A.A. Balkema, Rotterdam, viii $+143 \mathrm{p}$.

Delft University of Technology, 2011, SWAN - Implementation manual, available from http://www.fluidmechanics.tudelft.nl/swan/index.htm (Version 40.85, August 2011).

Hervouet, J.-M., 2007, Hydrodynamics of Free Surface Flows: Modelling with the Finite Element Method. Wiley \& Sons, Ltd.

Hjorth, 1975, Studies on the nature of local scour, Bull, Series A, 46, Deptament Of Water Resources Engng, Lund InstituteTechnology, Lund.Hoffmans \& Verheij, 1997, Scour Manual, Balkema, Netherlands, 9054106735.

Hughes, 1993, Physical Models and laboratory Techniques in Coastal Engineering, World Scientific.

Melville and Sutherland, 1988, Design methods for local scours at bridge piers, J. Hydraulic Engineering, ASCE, vol. 114, No. 10, 1240-1226.

Melville and Colemann, 2000, Bridge Scour, Water Resources Publications, LLC, CO, USA, xxii $+550 \mathrm{p}$.

Nielsen, Walker, 2001. Field data on the re-suspension of freshly deposited silts under wave action. Coasts \& Ports. Proc. of the $15^{\text {th }}$ Australian coastal and ocean engineering conference.

Migniot C., 1977, Action des courants, de la houle et du vent sur les sédiments, La Houille Blanche, 1, 9-47.

Soulsby, 1997, Dynamics of Marin Sands, Thomas Telford, UK, 072772584X.

Sumer, Christiansen, Fredsoe, 1993, Influence of the crosssection on wave scour around piles, J. Waterway, Port, Coastal and Ocean Engineering, ASCE, vol. 119, No. 5, 477-495.
Sumer, Christiansen, Fredsoe, 1997, Horseshoe vortex and vortex shedding around a vertical wall-mounted cylinder exposed to waves, J. Fluid Mechanics, 332, 41-70.

Sumer \& Fredsoe, 2002, The mechanics of Scour in the marine environment, World Scientific, Singapore, 9810249306.

Van Rijn, 1984, Sediment transport: Part 1: Bed load transport, Part II: Suspended transport; Part III: Bedforms and alluvial roughness. J. Hydraul. Div. Proc. ASCE, 110 (HY10), 1431-56, (HY11) 1613-41, (HY12), 1733-54.

Whitehouse, 1998, Scour at marine structures, Thomas Telford, UK, 0727726552.

Zanke, U., Hsu, T., Roland, A., Link, O., Diab, R., 2011, Equilibrium scour depths around piles in noncohesive sediments under currents and waves, Coastal Engineering, 58, 986991. 